\title{
The early British railway system, the Casson counterfactual, and the effectiveness of central planning
}

\author{
Andrew Odlyzko \\ School of Mathematics \\ University of Minnesota \\ Minneapolis, MN 55455, USA \\ odlyzko@umn.edu \\ http://www.dtc. umn.edu/ odlyzko \\ Revised version, February 11, 2016
}

\begin{abstract}
How large is the "first mover disadvantage," in which a pioneer in deployment of new technologies incurs costs due to the immature state of that technology and to lack of knowledge about its application? And to what extent can those costs be mitigated by careful study, or by central planning? Mark Casson's recent book, The World's First Railway System, demonstrates that the British rail system on the eve of World War I could have been replaced by a much more efficient one, with reductions of cost and mileage in the 25-35\% range. Much of that inefficiency can be attributed to the early days of British railways, in the 1830 s and 1840 s. It was due to incorrect notions about the nature of demand for railway service and about economic growth, notions that were recognized by only a few contemporary observers as incorrect. Since the correct views were rare and contrarian, it is likely (as was claimed by some experts in the early 1850s) that central planning in the 1840s would have led to an even less efficient system than the one produced by the decentralized, competitive, and admittedly wasteful historical process.
\end{abstract}




\section{Introduction}

Britain was the world's leader in the development of railways. Much of the development of the British rail network occurred in the early days, when little was known either of how far the technology would improve, or how much demand for it would exist. The resulting system was perceived by contemporaries and also by modern observers as inefficient. However, the degree of inefficiency had not been quantified by any careful study. This gap has been filled by the recent book by Mark Casson, The World's First Railway System [5]. It presents convincing evidence that at its peak a century ago, the British rail system had $50 \%$ more track than necessary. More precisely, Casson considered the railway system of Britain (meaning England, Scotland, and Wales, but excluding Ireland) of 1914, when it was close to its maximal route length with about 20,000 miles. In a prodigious feat for a single person, he produced a design for an alternate system of only 13,000 miles that he carefully argued would have provided an equivalent level of service. That represents a saving of $35 \%$ in mileage. Since his design would have required more facilities in some places, he estimated that his layout would have saved about $25 \%$ of the construction costs of the actual system ([5], p. 17). As cumulative railway investments in Britain amounted to about $60 \%$ of GDP by 1913 [20], even a $25 \%$ saving would have come to around $15 \%$ of GDP, a huge amount. Casson's smaller system would also have reduced operating costs to a substantial but unquantified extent. Since gross annual revenues of the railway industry were over 5.5\% of GDP in 1912 [20], any significant reduction there would have had a substantial impact on the efficiency and competitiveness of the entire British economy.

Most of Casson's book is devoted to the details of his alternate layout of the British rail network, and those are assumed to be valid in this paper. (It is even shown in Section 4 that similar estimates of the degree of wasteful spending in railway construction had been made in the early 1850s by some knowledgeable observers.) However, much of the interest in his study comes from his claim that had Britain made a modest change in government policy in 1845, most of the inefficiency he documents for the British rail network of 1914 would have been avoided. His suggested policy change would have continued and strengthened the expanded role that a certain government agency (the Railway Department of the Board of Trade, from now on referred to as RDBoT) had in railway planning for about a year, from mid-1844 to mid-1845. It is shown here that this part of Casson's thesis is very likely incorrect. It is more probable that greater government involvement in railway expansion in the 1840s would have produced an even less efficient system than the admittedly wasteful one that came to be. This was the opinion of some eminent railway engineers in the early $1850 \mathrm{~s}$, in the aftermath of the huge expansion of the railway network that resulted from the Railway Mania of the 1840s.

Casson is undoubtedly correct in much of his criticism of British railway policy. Had Parliament adopted a more interventionist policy in the second half of the 19th century, some of the inefficiencies that Casson identifies could have been avoided. However, during the crucial period of the 1840 s, there were additional and deep-seated obstacles to efficient design, going beyond lack of coordinated planning. One misleading notion that dominated British thinking in the 1840s was about the nature of demand for railway service. Another was about the nature of economic growth. 
First let us consider the nature of demand for railway service. Casson does note several points in his book (e.g., pp. 292-94) that so-called "direct lines," which connected pairs of major cities by routes as straight as feasible, and bypassed substantial population centers along the way, were popular in the 1840s. However, he appears to regard this as a minor point, one that would not have affected rational planners of the RDBoT. This is unlikely. In a modern phrase that arose in the computer industry some decades ago, "direct lines" were not a "bug," but a "feature." Direct lines connecting all major cities to London and to each other were regarded as an ideal by most of the early Victorians. This was just one aspect of the almost universal conviction among contemporary observers, in Britain as well as in other countries, that the main role and main source of revenues of railways was in connecting major cities. This is discussed in sections 2 and 6 ,

Direct lines are not always inadvisable. Modern high speed intercity lines, can be regarded as forms of what in the mid-1840s was sometimes called the "direct principle." The $\mathrm{UK}$ is considering building a new rail line, HS2, to connect London and Manchester, that would follow this "direct principle." But that is today, when the population is far larger than it was in the 1840s and there is far more travel. In the 1840s it was felt such lines should connect all major cities right then.

The importance of direct lines during the Railway Mania is illustrated by Sir Robert Peel, often regarded as the most influential politician of the era. He was the Prime Minister during the early and most ebullient phases of the Railway Mania, when the crucial decisions were made. Peel was an ardent supporter of direct lines. In June 1847, when the Trent Valley Railway (TVR from now on), one of the most prominent direct lines, was opened, Peel was the guest of honor. He had been a supporter of the line in its early phases, as well as of predecessor projects a decade earlier. (Section 5 has more detail.) In his speech in 1847, he praised the TVR for its adherence to the "direct principle." He said that when the Roman general Julius Agricola

determined on opening a north-western route ... he determined to take the direct line. ... he took undeviatingly the direct line ... I felt convinced, gentlemen, that if two thousand years ago this straight line had been preferred ... that a direct line would be selected under the more modern and more mighty road administration of the 19 th century. (Cheers.) $)^{1}$

By the early 1850s, after the collapse of the Railway Mania, direct lines were recognized widely as costly mistakes. Furthermore, some experts felt that had government planners been in charge, many more direct lines would have been built. Thus during a discussion in 1852 that involved many of the most eminent railway experts of the era, John Hawkshaw, a well-known engineer, declared (apparently without any counterarguments from the rest of the participants) [26]:

He dissented from the opinion, that great advantages would have arisen, if the Government had laid down, at the first, the lines which were to be followed. It was quite true, that a great deal of money had been wasted, that many mistakes had been committed, and that a larger dividend might have accrued to the shareholder; but this was nothing, in a national point of view, in comparison with the evils which 
Government interference would have created. Rigid unbending straight lines would have been laid down, and thus have prevented that large amount of accommodation which was now secured to the different towns in the kingdom.

Peel, Hawkshaw, and the 1852 meeting from which the above quote is taken are discussed in more detail in Section 11. It is impossible to be certain what central planning would have done to the British rail network in the 1840s. However, the evidence presented in this paper suggests that Hawkshaw may have been right, and that the outcome could easily have been even more direct lines and therefore more inefficiency.

The lack of appreciation of just how desirable direct lines seemed to the early Victorians is one of the two main fallacies of the Casson study. The other one is in the assumption about early Victorian growth expectations. Casson's counterfactual network is designed to accommodate the British traffic patterns of 1914. He connects the savings his system achieves over the actual one to the policy decisions of the 1840s by arguing that the early Victorians were planning for the growth that was observed over the next three quarters of a century ([5], p. 4). That is easy to disprove. We have abundant evidence of the business plans of the railway companies in the 1840 s, and they envisaged a substantially different industry than the one that existed in 1914. This is discussed in detail in Section 7 , A brief demonstration is given in Table 2. It shows that the private planners of the 1840s were not even able to plan properly for the demand of the 1850s, much less of the 1910s.

The general conclusion of this study is that Casson's thesis about the potentially beneficial effect of greater British government involvement in railway planning in the 1840s is questionable. However, this conclusion applies just to Britain in the 1840s, and does not show that industrial policy is always inadvisable. For that, more general investigations are necessary.

Government intervention in the 1840s would have been beneficial had there been enough awareness that the dominant notions about nature of demand for railway service and about economic growth were incorrect. However, such awareness would also have served to avoid the financial debacle of the Railway Mania even in the absence of government involvement, as investors would have known their profit expectations were bound to be disappointed. The problem was that almost all observers were not even aware there was any issue with their views.

Counterfactual designs of the high caliber of Casson's can be very useful, and should be carried out in several other contexts. The reason is that they are useful in gauging the "firstmover disadvantage," in which a technology pioneer incurs higher costs due to mistakes made in the early stages of deployment, when neither the capabilities of the technology nor the ways this technology is used by society are known well. Several early railway systems are suggested in Section 13 as worthy subjects for studies such as Casson's.

\section{Changing technologies and changing minds}

The Victorian era was one of great intellectual ferment. The spread of many new ideas (such as slave emancipation, greater democracy, and Darwin's theory of evolution) was reflected in wide public debate and extensive coverage in contemporary literature, and has 
been studied by modern scholars. Some ideas, on the other hand, appeared and diffused quietly, without any serious public discussion. Such was the path of the modern notions of economic growth and of locality of railway traffic that Casson assumes. They are indeed natural to us, but were utterly foreign to almost all British observers in the first half of the 19th century. This section discusses three prominent figures, prominent enough to deserve entries in the Oxford Dictionary of National Biography [18], who were pioneers in realizing the general public perceptions in these fields were incorrect. Table 1 shows when the thinking of those persons changed on the two key topics. It should be emphasized that these three were pioneers, and that these paradigm shifts came later for most investors, public policy makers, and railway managers.

Table 1. Dates when three prominent people adopted modern views on the importance of local traffic for railways and on the presence of steady incremental growth.

\begin{tabular}{lrr} 
person & $\begin{array}{r}\text { importance of } \\
\text { locality }\end{array}$ & $\begin{array}{r}\text { continuing } \\
\text { growth }\end{array}$ \\
\hline John Hawkshaw & by 1838 & after 1845 \\
James Morrison & mid-1846 & by 1836 \\
Dionysius Lardner & after 1835 & after 1838 \\
& and by 1846 & and by 1841
\end{tabular}

To be precise, one should distinguish between technological progress and general economic growth. In the interests of brevity, and also because for most 19th century persons it is hard to tell precisely what their views were, this is not done here. The only question that is considered is whether an individual thought growth came in rare spurts, as a result of a dramatic new technological invention such as the development of the railway or of a new business opening up through the cultivation of cotton in India, say, or whether there was a continuous process of incremental technological improvement or of economic growth.

Hawkshaw, 1811-91, was one of the most prominent civil engineers of the late 19th century and eventually became Sir John Hawkshaw. His 1838 report on the Great Western Railway (GWR), which criticized practically all the non-standard designs of Isambard Kingdom Brunel, that line's engineer, already showed that he envisaged railways as providing a meshed service, of the kind Casson proposed ${ }^{2}$. In his history of the GWR, E. T. MacDermot noted ([19], p. 41) that "[e]vents have shown that Hawkshaw was absolutely right in his views except [for one point]." However, GWR directors and shareholders rejected Hawkshaw's views, and backed Brunel's. Brunel envisaged the GWR system as an 
isolated one, devoted in the first place to linking Bristol to London, and in the second place to funneling traffic from the countryside to those two cities.

While Hawkshaw was early in recognizing the importance of local traffic, he was slower to absorb the notion of continuing growth. When he was asked by James Morrison in 1846 during a House of Commons committee hearing: "Is not it in the nature of railway traffic to increase?," he responded "Yes," but his responses to the preceding and following questions suggest that he did not include that naturally into his mental planning ${ }^{3}$.

James Morrison, 1789-1857, is often cited as a pioneer in utility regulation because of the 1836 speech he made in the House of Commons ${ }^{4}$. In that speech he expressly stated his view that technological and economic progress would continue for a long time. On the other hand, in the pamphlet [21] (reprinted in [22]) which he published in early 1846, he was a strong advocate of direct lines, and complained that "very large masses of people" were "imperfectly supplied by circuitous routes." However, in mid-1846, the work of HenriGuillaume Desart, a Belgian civil engineer, on gravity models for railway traffic became known to a substantial number of British observers, as is described in [25]. The interchange in July 1846 between Morrison and Samuel Morton Peto, the famous contractor, during hearings before Morrison's committee showed that both knew of Desart's breakthrough, but both had somewhat confused understanding of it. This was reflected in Morrison's famous "2nd report," reprinted in [22. Although Morrison and Peto talked of the importance of local traffic, they were also supportive of direct lines. Shortly thereafter, though, Morrison may have realized the inadvisability of direct lines, as his 1848 tract [22] does not mention them, in great contrast to his 1846 work [21].

Dionysius Lardner, 1793-1859, was a famous science and technology popularizer. In early 1836, as the first large railway mania in Britain was raging, he published the 5th edition of his book on the steam engine [15]. Among the revisions from the previous edition was the addition of a chapter entitled "Plain rules for railway speculators," which was widely reprinted in the press. The general emphasis was on traffic between terminal cities. But there was a small hint of a change in opinion, in that the second "rule" was altered between the 5th and 6th editions of the book, to reflect the fact that passengers on the Liverpool and Manchester Railway were not traveling just between those terminal cities, but also to and from "the principal neighbouring towns." A decade later, Lardner's tone was decisively different. In his 1846 survey of railways [17, he wrote that "[u]nquestionably the general impression was, and, so far as we have observed, still is, that the great mass of their traffic is derived from the large cities and towns at their termini," and then proceeded to produce statistics to disspell this impression. After some discussion, he concluded with an emphatic statement "that the terminal populations have but little connexion with the financial success of railway projects. The main support is short traffic."

The popular press, and even some history books, treat Lardner as a laughing stock because of his skepticism about the feasibility of steam travel across the Atlantic. He was indeed the most prominent skeptic, although by no means the only one, of the ventures being planned in the late 1830s. It appears that Lardner was led astray by relying on dated statistics about the efficiency of steam engines. While he was an ardent prophet of technological progress, in common with most people he seemed to think (at least through 
1838) of this progress as coming in quantum jumps, and regarded the data he was using as still applicable to the best engines of 1838 . But by 1841 , we find him writing (without admitting he had changed his mind) of continuing progress ([16], pp. 250-51).

\section{The inefficiencies of the British rail network: General views}

Casson claims that his estimate of the waste in the British system is far higher than any previous one ([5], p. 2). However, there were numerous observers around the middle of the 19th century who had put forth similarly high or even higher estimates of the waste incurred. In this section and the next one we consider a few examples.

In the 1840s, the British public, as well as the ruling elite, believed widely that their rail system was inefficient. There were frequent comparisons in the press with other countries' much lower railway construction figures, and allegations that it was corruption, incompetence, and extravagance that resulted in the high costs for British railways. One of the many instances of this is the famous series of letters published in The Times in the fall of 1846 under the pseudonym "Cato." They represented a concerted effort by The Times and James Morrison to alter the course of British railway policy [9]. They are full of claims that the British system was too expensive. As just one example, one of those letters provided an estimate that established railways in Britain had cost $£ 34,000$ per mile, and that this involved "an unnecessary costs of upwards of $[£ 15,000]$ per mile" 5 .

There was also wide belief that much of the inefficiency of the British rail system of the early 1840s was due to the novelty of the technology. Thus a long and thoughtful piece in The Times at the end of 1844 claimed that "[s]carcely any one conversant with the subject will deny that the existing railways ... could now be constructed for half [the amount they cost], in consequence of engineers having now gained the necessary experience" 6 .

The huge inefficiencies, of $50 \%$ in The Times piece just cited, or over $40 \%$ in the Cato letter earlier, are even higher than those estimated by Casson. However, they were made by writers who probably had little knowledge of engineering, and in rather polemical pieces, so are hard to take seriously.

\section{The inefficiencies of the British rail network: Expert views}

There were also estimates of the British network inefficiency comparable in magnitude to Casson's that do deserve to be considered seriously. This section discusses three, all made in the early 1850s, in the aftermath of the collapse of the Railway Mania. They are not exactly analogous to Casson's. They are not detailed, and it is not even clear what kinds of changes some of them envisaged. Most important, Casson offers an alternative layout for the British rail system of 1914, designed to satisfy the needs of the British economy of 1914. Those earlier observers were discussing potential savings in the buildout of the British rail system of the early 1850s, when it had about 7,000 miles, as opposed to about 20,000 miles in 1914.

The two British observers, to be treated first, were Samuel Laing and Robert Stephenson [18]. Laing (1812-1897) was one of the "Five Kings" of the RDBoT, and in the early 
1850s was Chairman of the London, Brighton, and South Coast Railway. Stephenson (18031859) was the most eminent of the British railway engineers of the 1840s and 1850s.

In early 1853, during the Cardwell Committee hearings on railways, Laing stated that about $25 \%$ of the cost of the British rail system had been wasted ${ }^{7}$. Laing did not present any detailed estimates or alternate designs for the British rail system, and his estimate appears to have been an ad hoc one, made in response to the question he was asked, and without any serious study.

Stephenson was in the audience during Laing's testimony, and had several days to think about it before he was called to testify. Hence his estimates can be considered as more authoritative, especially since he was an engineer, whereas Laing had a legal and managerial background. Stephenson thought the waste in the contemporary system was somewhat smaller than Laing's estimate, in the range of $14-18 \%$, but he was not too certain. A few months later, in a speech in Montreal, he raised his estimate to $20 \%{ }^{8}$. A few years later Stephenson mentioned an even higher figure, about 25\%, which is just about Casson's estimate ${ }^{9}$.

Across the Atlantic, an interesting observer thought the waste was even higher. Henry Varnum Poor, at that time the editor of the American Railroad Journal, reprinted Herbert Spencer's essay "Railway morals and railway policy," and provided extensive commen$\operatorname{tary}^{10}$. Spencer cited Laing's estimate of about 25\% waste in British railway system. Poor himself thought the waste was even higher, at least $33 \%$ ([27], p. 105). However, his higher figure for waste was based on a fundamentally different philosophy of railway construction, which will be mentioned in Section 13 .

\section{The wide spread and persistence of the direct lines delusion}

The next section will delve into the origins of the direct lines preoccupation. This section presents several illustrations of how strong and how pervasive this delusion was during the Railway Mania. The first one features Sir Robert Peel. The Introduction cited his enthusiastic endorsement of the "direct" Trent Valley Railway (TVR). The TVR was designed to provide a more "direct" communication from London to Liverpool and to Manchester by bypassing Birmingham. That it was regarded as a direct line did not stop other promoters from setting up projects for even more direct lines. In 1845, there were two serious proposals that had the same name, the Direct London and Manchester Railway. (They were usually distinguished in the press by attaching to them the names of their chief engineers.) One of them had on its provisional committee John Gladstone, the father of the future Prime Minister, who was a very wealthy and respected merchant and an early and large railway investor ${ }^{11}$.

In 1839, when an unsuccessful predecessor to the TVR, the Manchester and Birmingham Extension Railway (MBER), was debated in Parliament, Peel called arguments against it "preposterous" and some "the most indecent ever offered [in the House of Commons]" 12.

During a debate in the House of Commons on 20 March 1845, Peel gave a speech in favor of direct lines, and the TVR in particular. The RDBoT had reported a week earlier in favor of the TVR and another, related, line, the Churnet Valley Railway, in a report 
that was perceived as very enthusiastic about direct lines. The RDBoT declared those two schemes, together with existing railways, "[complete] a line of Railway communication between London and Manchester ... which is believed to be practically as short a line as any which can be made between the two points" ${ }^{13}$. While Peel did not name the TVR, it was clear that is what he meant, as he explained that its current progress was a justification for the course of action he had urged back in 1839, when the MBER was under consideration. He claimed that finally the wisdom of building direct lines was being recognized.

Eight months later, when work on the TVR was about to start, Peel was asked to turn the first sod. In his speech, he again had rhapsodic words for direct lines ${ }^{14}$. In June 1847, when the TVR was officially inaugurated, Peel, although no longer Prime Minister, was again the guest of honor, and his encomium to direct lines, with its invocation of the wisdom of the Roman rulers of England, was cited in the Introduction. At this last occasion Peel's praise of direct lines did not go entirely uncontroverted. George Stephenson made a short speech towards the end of the festivities. In the blunt (some called it tactless) style that was characteristic of Stephenson, he criticized not only direct lines but also a few other railway innovations that Peel had at one time or another been enthusiastic about. Still, it is not clear how many of the attendees supported his views, as the notion of direct lines had not yet been fully discredited in the public eye at that time. Few press reports of the event even mentioned Stephenson's speech, and even fewer cited his critiques.

Another, and perhaps most interesting example of direct line enthusiasm is presented by the evolution in the published opinions of The Times. At the time of the Railway Mania it was a uniquely influential press organ, with circulation greater than that of all other London dailies put together. At the start of the Railway Mania, The Times appeared to take a somewhat skeptical attitude towards direct lines. At the end of 1844, it carried a long piece on "The Railway System and the Board Of Trade"15. About direct lines lines it had the following to say:

Direct lines of railway are now much in fashion: but direct lines of railway which leave out the intermediate traffic, or merely connect important towns by short branches, may produce irreperable local injury, and by being in themselves less remunerative would produce many of the evils we have pointed out.

All very insightful and sensible, and, in retrospect, completely correct. But it was opposed to the prevailing trend of thought.

Later, as time passed, and the general enthusiasm for direct lines grew, the tone of The Times started changing. At the end of 1845, a leader came out strongly in favor of direct lines, claiming the country was "involved in a labyrinth of railroads, and it is as much [Peel's] fault as any other man's that we have not more direct lines" ${ }^{16}$. A few days later this was followed by an even stronger leader:

The [RDBoT] last year, careful and painstaking as it was, did not succeed. It failed to win the respect of the Legislature. In one important point it ran counter to the obvious necessities of the case, and the opinion of all unprejudiced authorities, including the Premier himself-viz., in favouring existing railways, to the prejudice of direct lines. Its idea was a system of endless ramifications, with as few trunks as 
possible. The result of such a plan would be a maze of railway, devious with branches, and knotty with junctions, which might be partially convenient to some localities, but would be generally inconvenient to the whole. But this is the prevailing error of our railway communications. Why must a man wind about or zigzag over half England because he wants to go to Edinburgh, to Exeter, or to Dover? ${ }^{17}$

It is noteworthy (and relevant to later discussion of the RDBoT in this paper) that The Times blamed the RDBoT for not supporting direct lines. Others, especially later, blamed it for the opposite reason, namely embrace of direct lines, as in its endorsement of the TVR.

Aside from satire, British press did carry a few items (primarily letters to the editor) skeptical about direct lines. But they were almost uniformly based on subjective opinions. Perhaps the closest to a convincing quantitative argument that has been found is in a series of pieces in one of the railway papers in early $1846^{18}$. They did argue that local traffic was important, and there would not be enough demand to pay for the direct lines.

\section{Locality of traffic and gravity models}

Casson does treat direct lines several times in his book, most extensively in Section 7.9 (pp. 292-94). He ascribes their popularity to a desire to prevent competition from other railways, and also to a desire by terminal cities to avoid competition from towns that were being bypassed. He regards the second reason as the less important one, and this is consistent with the findings of this author's studies. Except for special cases, merchants in large cities often did extensive business with towns in the vicinity, and were interested in better ways to reach them. As for the first reason, competition, it did play a central role, but in a complicated way that needs to explained, since it was grounded in a misunderstanding of how railways would be used.

In the $1830 \mathrm{~s}$, when many of the early trunk lines were laid out, competition was not much of an issue, the main concern was about viability of the novel railway technology. This changed in the 1840s. Thus, for example, we find John Wilson Croker, a famous politician, writer, and public intellectual [18], declaring at a meeting of the London and Southwestern Railway (LSWR) in 1847 that only direct lines could succeed, and "circuitous lines would not do, ..., there was no safety for railway property except by taking the shortest line" 19 . The concern there was about new direct lines springing up and taking away traffic from established ones. The main reason this was thought to be a threat is because of an exaggerated view of the importance of traffic between terminal cities.

The main drive for direct lines before and during the Railway Mania reflected a general conviction, not just in Britain, but also in continental Europe and America, that the main purpose of railways was to connect pairs of major cities, and that most of rail traffic would be between such pairs of major cities. As just one example, consider the London and Brighton Railway. There was a fierce Parliamentary battle among about half a dozen competitors in 1836, and the scheme selected by the House of Commons (the most direct of the proposed lines) was turned down by the House of Lords. The following year, a study on

the smaller number of survivors was commissioned from Captain Robert Alderson of the 
Royal Engineers. He reported ${ }^{20}$ that he had "no hesitation in stating, that the line proposed by Mr. [Robert] Stephenson, considered in an engineering point of view alone, is preferable to either of the others." However, considering the nature of the region the line would go through, he decided to concentrate on "the accommodation [candidate lines] afford to the metropolis at one end, and the town of Brighton at the other." This led him to "adhere to the opinion already given in favour of the direct line [by Rennie]." Thus in this case an engineer decided that it was not engineering excellence that should be primary criterion for selection, but the directness of the line. That was just a reflection of the prevailing public opinion.

Opinions such as those of Captain Alderson were consistent with the business plans that railway companies advertised in their prospectuses and submitted to Parliament. Those generally projected in a quantitative form that the bulk of revenues would come from long distance travel. As just one example, consider the Manchester and Leeds Railway, a 60.6mile line that was sanctioned by Parliament in 1836. The House of Commons committee on its proposal reported that its business plan projected 442,000 passengers per year, "equivalent to 226,733 and a fraction, along the whole line" ${ }^{21}$. Thus the average length of a passenger trip was expected to be 31.1 miles. However, the actual average trip length in the first half of 1843 was 14.4 miles (or 16.6 miles if we weight the trips by the ticket price, as first class passengers on average traveled further than those in second or third class) [11. Thus expectations were far from reality, and this was common. Many of the reports of the House of Commons committees on railways provide enough data to deduce what the expected trip lengths were. In most cases those reports show that those lengths were overestimated, often by about a factor of two, as in the case of the Manchester and Leeds project.

As time went on, awareness of the importance of local traffic started to spread. Section 2 showed approximately when Hawkshaw, Lardner, and Morrison adopted modern views. But they were pioneers, and most British observers were slower. Part of the reason was lack of data and lack of familiarity with quantitative thinking. For example, as was already mentioned in Section 2, Hawkshaw in his report on GWR in late 1838 laid out a vision of railways concentrating on providing excellent local service. But this was a soft vision, without any hard data about travel patterns to substantiate it.

The paper [25] discusses in more detail how British observers learned (and often refused to learn) about the importance of locality of railway trips. Had they paid attention to the issue and collected more information, they could have learned enough to avoid the mistake of direct lines and other ventures. However, they did not do this. Even when they learned of Desart's discovery in Belgium of what are now called "gravity models for spacial interaction," which are a basic tool of modern transportation planning, they usually misinterpreted it. That is what Morrison and Peto did, as was discussed in Section 2, That is also what the Morning Chronicle, an important London daily, did in one of its articles. In its account, it not only presented a garbled account of Desart's work (on top of misspelling his name), but it concluded that it was a curiosity of continental European traffic patterns, as things were "the reverse in England" 22. 
It is worth noting that the Casson counterfactual design for the British railway network relied on gravity models to estimate the demand for service between pairs of cities. The railway planners of 1845 did not have such tools. Hence even if they had been able to project what the populations of cities were going to be in 1914 (something that was to a substantial extent the result of railway development, and not an exogeneous factor), they would not have known what the precise traffic demands would have been.

As the Railway Mania was inflating in 1844 and 1845, the knowledge of the importance of local traffic, and therefore of the inadvisability of direct lines, was growing slowly. On the other hand, the opposing tendency, the desire for direct lines, was rising rapidly. Thus we find the Economist in late 1845 declaring about the GWR that in the ignorant early days of the industry, "[t]hey wended their way from town to town, unable to see that direct lines would ultimately be demanded for public convenience" and would now have to undertake expensive construction to rectify those mistakes ${ }^{23}$. With increasing willingness of investors to provide funds for railway expansion, many observers, such as the writer of the Economist piece above, saw direct lines as something that was finally becoming attainable, a goal that had been compromised away earlier when money was tight and the viability of the railway industry was in doubt.

A substantial contributor to the enthusiasm for direct lines during the Railway Mania was the hope that new railways would be constructed at lower costs. The quote from The Times at the end of 1844 in Section 3 referred to the widespread opinion that because of the experience the industry had gained in the preceding decade, construction costs would be half of what they had been. Lardner in his 1846 survey [17] noted that existing railways in Britain had cost about $£ 35,000$ per mile, and that the lines sanctioned by Parliament in 1845 were supposed to cost $£ 16,268$ per mile. Hence the picture that was dangled in front of potential investors in new direct lines meant to compete with established ones was an alluring one. They could build out their project to provide what was felt to be the main desideratum, namely connection between terminal cities, at lower cost, and so could offer lower prices to lure away the traffic that the older line had proved existed. Since they were going to offer a superior service, they could overcome opposition in Parliament to duplicate lines, and could then hope to drive the established line into the ground (or else force it to buy up the new project, as happened with the TVR). With hindsight, we can say that those hopes were misplaced, costs were not going to be as low as promised, and rapid travel between terminal cities was not the main source of revenues. At the time, though, those hopes were widely held. There were contrarian voices, but they did not receive much attention (at least in the surviving printed record, which is not necessarily an unbiased representation of the views of the various groups).

\section{Growth rates}

The dominant view in Britain until 1850 was that infrastructure investments, such as canals and railways, would produce essentially constant revenues and profits. Not a single prospectus has been found from this period that mentions continued growth in traffic as an expectation. There are frequent citations of prospects of increased revenues as a result of some new business developments (new connecting railways being built, a coal mine opening 
up close to the line, etc.), but these were understood to depend on exogenous events and to be uncertain. In addition, House of Commons railway committees were required, between 1836 and 1845, to report on the business plans of the railways they were recommending for approval by Parliament. Not a single one of those reports projected continued growth in traffic.

There was awareness of the population growing at about $1.5 \%$ per year, but that was low enough that it was seldom discussed, and was not incorporated into business plans. The assumption was that once a railway started serving customers, there would be a "development of traffic" to a steady level. This basic assumption was seldom stated explicitly, because there was no need to state it. Practically everybody (with a few exceptions, such as James Morrison as early as 1836) just knew that this is how the world ran. This section cites just a few illustrative examples, mostly of cases where people were realizing the consensus view was not correct.

The general expectations among railway observers during the Railway Mania seemed to be that the "development of traffic" to its full potential on a new line would take at most a year or two. In early 1848, as unease about their lines' prospects spread among railway investors, George Hudson, the Railway King, attempted to pacify his shareholders. He declared that "it could not be expected, that, upon the immediate opening of new lines ... traffic ... should be suddenly developed, three years being the average time usually allowed for that process" 24 . But the clear implication of this statement is that he was still expecting revenues to level off, it's just that it would take a bit longer than his impatient and nervous audience expected.

In citing public pronouncements by prominent figures there is always the question of whether what is cited is representative, and also of whether it reflects the speaker's true belief. In the case of Hudson and other railway industry figures in 1848, though, their true beliefs are not very important. They had a strong interest in reassuring investors that the declines in dividends that most lines were suffering from were temporary. And what better way to provide such reassurance than by citing the prospects of a long period of rising revenues? That Hudson and his fellow managers did not do so is a strong indication that they felt such claims would not be regarded as credible by their shareholders.

There was a rise in awareness of continued growth, but it was slow, and not without controversy. In the fall of 1849, The Times, which had been the fiercest critic of the Railway Mania, surprised many by publishing a prominent leader with a positive message for railway investors $^{25}$. At that time the railway share market was at about its lowest level, reeling from declining dividend rates and the disclosures of George Hudson's frauds and accounting irregularities at other lines. The Times, though, predicted that profits would improve, and advised railway shareholders not to sell their shares. The basis for this optimism was a forecast, based on the progress of transportation over the previous three quarters of a century, that by 1875, "the internal travelling and traffic of this nation will be nearly doubled, if not more."

This was a bold forecast for that period. Population growth of about $1.5 \%$ per year would have suggested an increase in traffic of about $47 \%$ in the 26 years from 1849 to 1875. Robert Lucas Nash the elder, a pioneering financial analyst, whose contribution to 
the collapse of railway share prices in late 1848 was greatly augmented by the publicity that The Times had provided for his work, cf. [24], broke with his old ally. He declared that The Times was acting on "expediency rather than principle," and that it was offering "visionary estimates of increased traffic" to its readers ${ }^{26}$. As it turned out, the doubling of revenues that The Times thought might take until 1875, and that Nash regarded as purely "visionary," took place by 1857, in just 8 years.

The 1850s were the first decade of "the great Victorian boom," which ushered in fast and relatively steady growth in the economy. Hence by the middle of that decade, it was more common to hear comments about, and expectations for, further growth in railway traffic. Still, this view was not held universally even then. In 1856, in his inaugural address after election as President of the Institution of Civil Engineers, Robert Stephenson felt it necessary to note that "[t]here has been no instance, in the annals of any railway, where the annual traffic has not been of continuous growth" 27 This reminder may have been needed. Just the year before, Edwin Chattaway, a railway engineer and manager, published a wellregarded survey of the railway industry. In that work, he claimed ([6], p. 27):

The traffic returns seem to have reached their culminating point, and, save in a few exceptional cases, the probability of any appreciable increase under this head is very remote.

\section{Railway expansion}

Given the expectations for a couple of years of "development of traffic" on new lines, and then static revenues, as outlined in the preceding section, it is clear that investors and government policy makers during the Railway Mania were not planning for the rail transportation needs of the British economy of 1914, which is what Casson's network is designed for. But what were they expectations? That is hard to say. Most promoters, engineers, investors, ..., were thinking of their particular projects, not of the shape of the entire national network. Still, it appears that the general consensus was that Britain was going to need, and would have, between 20,000 and 30,000 miles of railway, roughly the extent of the turnpike system. The disagreement was largely about the speed with which this network was going to be constructed. Thus on one hand the expectation was for an even more extensive network than the actual one of 1914, and on the other for a network with a far lower intensity of traffic (and of capital investment).

An example of this kind of thinking is implicit in James Morrison's 1846 pamphlet [21]. In some ways it was amazingly accurate. He explicitly declared that he expected cumulative railway investment to reach $£ 560$ million "in some 20 or 30 years." As it turns out ${ }^{28}$, total capital investment reached $£ 560$ million in 1872, 26 years later. He did not mention the size of the network, but implicit in his discussion, which cited the lines recently approved by Parliament, is the expectation of costs of about $£ 20,000$ per mile, which would have given a network of about 28,000 miles, considerably larger than the actual network of 1914 .

The 1853* figures in Table 2, which are listed as representing investor hopes at the height of the Railway Mania, were obtained as follows: The mileage figures were those for all the lines authorized for Britain through the end of 1852, primarily during the Railway Mania, 
Table 2. The development of the railway system in Britain

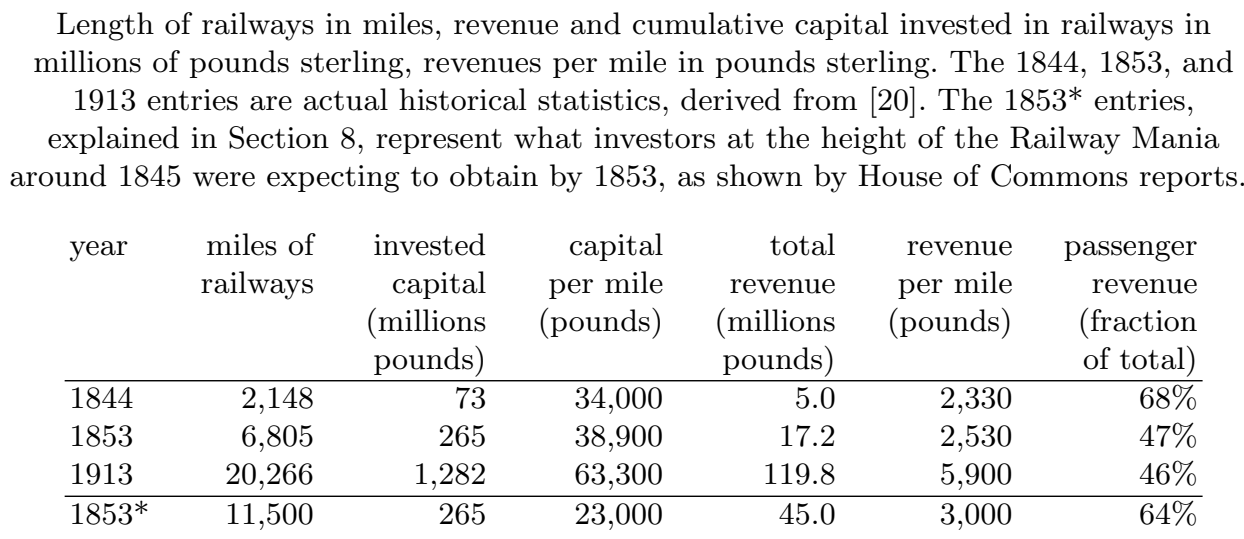

which is here taken to refer to the period from 1844 to $1849^{29}$. The capital per mile figure is approximate, mixing the lines in service at the beginning of the Railway Mania, which cost over $£ 30,000$ per mile, with the new ones, which engineers and promoters were promising would be built for about $£ 20,000$ per mile ${ }^{30}$. The $64 \%$ figure for revenues that were to come from passengers was derived by considering the business plans of the British lines approved during the 1844 session by the House of Commons ${ }^{31}$. As for revenues, the lines authorized during the 1845 session promised an average dividend of about $6.4 \%^{32}$. These promises were based on the systematic demand estimation methodology that was sanctioned by Parliament. However, as is shown in Section 22 of [23], investors were hoping for $10 \%$ profit rates. To achieve that, with average costs per mile of $£ 23,000$ and an estimated working expense ratio of about $33 \%$, their railways had to produce average revenues of about $£ 3,000$ per mile.

Many of the estimates that went into the $1853^{*}$ entries in Table 2 are thus somewhat arbitrary, and one could easily justify modifying them somewhat. The point remains, though, that during the Railway Mania promoters and engineers were not thinking of a rail system designed for the needs of the economy of the year 1914. They expected passenger revenues to dominate (and we have many citations from the period around 1850 expressing surprise at the vigorous growth of freight traffic), and thought lines would cost far less to build, and would attract lower revenues per mile.

\section{A "directing genius" and potential for efficient design}

In the case of the British railway system, there were some engineers who likely would have devised a better layout than was actually constructed, had they been given a free hand. John Hawkshaw almost surely would have. Already in the late 1830s he had a good intuitive sense for the patterns of rail traffic, and the network architecture that was needed. Robert Stephenson might also have have provided a better layout. In his summer 1853 lecture in Montreal he declared that "[l]ines had been located, which never would have been built, had a directing genius presided over the chartering of them" ([12], vol. 2, p. 183). He was 
surely thinking of himself as the genius who would have come up with an efficient design. It is quite possible that he would have. As is noted by Casson ([5], p. 21), Stephenson did lay out some regional networks. Furthermore, at the Cardwell Committee hearings early in 1853, he declared that railways had not been "laid out ... in the best possible direction for the public" due to the preoccupation with direct lines ${ }^{33}$. This was certainly an emphatic denunciation of direct lines (which was reinforced by the rest of Stephenson's testimony). But it may also have been colored by the benefits of hindsight. At the height of the Railway Mania, one of the most prominent of the proposed direct lines was the Manchester and Southampton Railway. The engineers for this line were the eminent George Parker Bidder and his long-time partner and even more eminent Robert Stephenson!

While engineers were sometimes the initiators of railway projects, especially when there was little new construction and they were looking for work, they were in general not independent agents, and were subordinate to those who controlled the purse strings. (Casson's claim, p. 55 of [5], that it was "engineers who masterminded strategy in the early years" does not seem to be representative, although it may have applied to Brunel's lines.) Thus when John Miller, best known for his work on Scottish railways, was asked by a Parliamentary committee in 1846 about choice of a direct line or one designed for "accommodation of the local traffic along the line," he responded that the choice was made "arising from the different objects of the promoters" 34 . Thus whether particular engineers were involved with direct lines or not does not necessarily say much about what they honestly thought was best. Hopefully more research into private papers of engineers, promoters, and managers from this period will provide more information on their opinions about optimal railway design.

\section{The Railway Department of the Board of Trade (RDBoT)}

Given the consensus among the early Victorian contemporaries about presence of large inefficiencies in the British railway system, could the RDBoT have achieved the savings of Casson's counterfactual system, had it been given the mission Casson recommends in 1845 ? The answer is almost certainly no, for a combination of reasons.

The first obstacle is that by 1845 it was too late to avoid some of the inefficiencies of the British system, as many basic decisions had been made a decade or more earlier. Thus, for example, Casson's counterfactual design has a single trunk line serving to connect London with Southampton and Bristol. However, by 1845, each of those cities had its "direct" line. Both were very profitable, and one of the most prominent direct line projects of 1845 was the Direct London and Exeter Railway. It was to run between those two, and was supported by The Times and James Morrison, although nothing came of it. There was still much that could have been done to make the system more efficient, as there were only slightly over 2,000 miles in service. But the RDBoT was not dealing with a tabula rasa.

The second obstacle to RDBoT's constructing an efficient railway system was that it had neither the mandate nor the competence to do so. Gladstone certainly did wish to give it such a mission. But then he also wanted more radical moves, including eventual government ownership of railways. The opposition was too strong for most of his proposals. The RDBoT was only to examine proposals brought to it by promoters. There were only 
a few small back doors to planning, as in the recommendation the RDBoT might, in evaluating a submission, take into consideration "a preferable scheme [that] is in bona fide contemplation, although not sufficiently forward to come simultaneously [to Parliament]" 35 . Note that the RDBoT was allowed to consider only projects that were well under way, not ones they thought up themselves.

Casson writes that the RDBoT "published detailed recommendations regarding the future structure of the network in 1845, based on over 20 detailed regional plans" ([5], p. 2). That is very questionable. The RDBoT did not publish detailed recommendations for the structure of the network. It published general guidelines (many reprinted in [5], pp. 23638). It then made detailed evaluations of proposed submissions and recommendations for Parliamentary action.

The RDBoT was also less of an outlier in British railway policy making than reading Casson's book might make the reader think. Parliament was taking steps other than setting up the RDBoT mission to bring more cohesion to its decision. The House of Commons, as just one example, set up the Select Committee on Railway Bills Classification, to assign railway projects that were competing or related to the same committee. Further, as Casson notes, "almost all of the recommendations of the Board of Trade were accepted by [Parliament in 1845]" ( [5], p. 238). House of Commons committees on railway projects of that year had to report on the degree to which they followed the RDBoT recommendations, and those reports were summarized conveniently in a book [3]. With a few notable exceptions, the differences were neither numerous nor large.

Phasing out the RDBoT scrutiny of railway projects does not appear to have made a very large difference. Casson writes ( [5], p. 239) that "[t]he 'agenda' for 1846 therefore became to approve as many schemes as possible, and without the [RDBoT] there was no effective check on Parliament." This claim is hard to accept. During the 1845 session, Parliament, relying to some extent on the advice of the RDBoT, passed 121 railway acts based on consideration of 249 schemes. In the 1846 session, when presented with 558 projects, and without any assistance from the RDBoT, it passed 272 acts, for an almost identical $49 \%$ success rate ${ }^{36}$. That more than half the submitted projects were rejected also serves to qualify Casson's repeated claims that MPs were reluctant to make hard decisions (e.g., [5], p. 18). They often made hard decisions, because they had to. In very many cases, they were faced with directly competing proposals, and they had to select just one.

In addition to lacking a mandate to design the British railway system, the RDBoT lacked the expertise to do it. In general, the RDBoT was perceived as lacking the gravitas appropriate for its role, and it did not have any railway engineers on its staff. Hence a railway paper complained that the RDBoT consisted of "a juvenile peer, one or two specially juvenile barristers, a theorist "closet-man," and a ci-devant Secretary "to some railway in the North" "37. While this was an extreme attack on the RDBoT, other, more respectable, sources were often almost as scathing. Thus The Times, the epitome of Victorian respectability, also criticized the members of the RDBoT, one-by-one. Of Dalhousie, the head of the RDBoT, it wrote that he was "a young nobleman whose knowledge of these subjects, if he possesses any, must be intuitive, as on none of these points can he have had any practical experience" 38 . The Times concluded that the RDBoT "does not possess the 
ability for the present duties it has to perform; and even if it did possess the ability, it would be utterly impossible for it to investigate with the necessary care a quarter of the new railway schemes now under consideration."

Suppose, though, that by some miracle, the RDBoT had been given the mandate to plan the British railway system, and had been headed by a senior duke to give it respectability, with a couple of prominent railway engineers to do the technical design work. Would they have produced a system as efficient as Casson's? It is essentially inconceivable that they would have anticipated the growth of the economy and of railway traffic in particular, and so they would not have planned for the demands of 1914, as Casson did. Further, the RDBoT was generally supportive of direct lines (as in its positive evaluation of the TVR), although not as enthusiastic as The Times at the end of 1845 thought it should have been, as shown in the 19 November 1845 leader quoted in Section 5. But the RDBoT did its work in late 1844 and early 1845, when the enthusiasm for direct lines was still far from its peak. Given the strength and pervasiveness of the mania for direct lines, documented earlier in this paper, chances are that a greatly empowered RDBoT would have partaken of the delusion, or had it imposed on them by an explicit mandate by Parliament.

\section{British railway experts in early 1850s and government planning}

The conclusion of the preceding section that strengthened government planning in 1845 would likely have produced an even less efficient system is supported by opinions of many of the top railway experts in the aftermath of the collapse of the Mania.

The quote from Hawkshaw in the Introduction about "the evils which Government interference would have created" through imposition of "[r] igid unbending straight lines" comes from a series of meetings of the Institution of Civil Engineers (ICE) a few years after the Railway Mania had deflated. On 27 April 1852, Braithwaite Poole presented a paper, "The economy of railways as a means of transit, ...," which led to extensive discussion that also consumed the next two weekly meetings of the ICE (and thereby forced an unscheduled postponement of lectures planned for those slots). Poole's paper together with a very detailed report (although not by any means a verbatim transcript) of that discussion was printed by the ICE [26]. Poole advocated amalgamation of railways of Great Britain into four territorial divisions. He claimed that "the Government [should have] determined the directions in which railways should have been constructed." This brought out Hawkshaw's rejoinder, quoted in the Introduction. In attendance and participating in the discussion were almost all of the most prominent railway engineers of that era (including Stephenson, Locke, Bidder, and Brunel) as well as some other influential railway figures (such as Captain Mark Huish). Since there is no record of any of them objecting to Hawkshaw's claims, it seems safe to conclude that they found them credible.

A year later, during the Cardwell Committee hearings, Robert Stephenson, in the passage partially quoted in Section 9, also blamed the preoccupation with direct lines for much of the inefficiency of the British railway network. These explicit declarations of Hawkshaw 
and Stephenson serve to confirm the conclusion that central planning of British railways in the 1840s would not have been conducive to efficiency.

\section{British central planning in the 19th century}

Grahame Boyes asked, in his review of Casson's book, whether the policy change advocated by Casson was really feasible in the 1840s [4. Gordon Biddle, in a letter commenting on the Boyes review, went further, and asserted that he was ready to "dismiss" the Casson work, and that counterfactuals such as that of Casson are pointless [2]. Biddle's argument was that "[t]he UK's railway system is what it is because of nineteenth century social, political and economic beliefs and practices, and the technology available at that time," There is certainly much to be said for this view, since the same railway planning process, with the same widely acknowledged deficiencies and inefficiencies, continued for the rest of the 19th century. Laissez faire was the reigning doctrine, and markets were expected to be regulated by competition as much as possible. James Morrison's was a lonely voice back in 1836 in the advocacy of railway regulation.

Still, the early Victorians were pragmatic (as is noted by Casson, e.g., [5], p. 30), and government was heavily involved in the railway enterprise, not least because railway promoters needed government permission to acquire property from often reluctant landowners. (The extensive literature on this topic is represented by [13,14.) British policies were heavily influenced by the abundance of capital in the country. When they wanted to accomplish something that purely private capital was not willing to carry out, those early Victorians often did go against their laissez faire principles. Thus, for example, James Wilson, the founding editor and proprietor of the Economist, was one of the most doctrinaire of the free market advocates. Yet, as a government official, he worked hard to bring railways to India, then a British possession, and "he certainly elaborated,--and he believed that he originally suggested,--the peculiar form of State guarantee" that was used to finance those railways ([1], pp. 26-27). British government also provided loans for the construction of Irish railways in the $1850 \mathrm{~s}$, in another controversial departure from the dominant dogma.

It seems possible that a centralized planning process of the kind envisaged by Casson could have arisen and produced a far more efficient system if the following two facts had been widely foreseen (for the first) or recognized (for the second) at the start of the Railway Mania of the 1840s:

- railway investments of the 1840 s were going to be largely unprofitable

- railway revenues were coming primarily from local traffic

Neither of these facts went counter to any basic and deeply held religious, political, or socioeconomic dogmas, and so could have been incorporated into public and private railway planning relatively painlessly. Had there not been a plethora of private capital eagerly chasing (illusory, as it turned out) profits, British elites might have resorted to a more systematic planning process. That was done in India under Dalhousie (who surely benefited from his experience as the head of the RDBoT during its critical 1844-45 period). It was also done for Ireland in the late 1830s, when a royal commission was set up to consider railways 
in that country. This commission spent almost two years, assisted by two experienced railway engineers, Charles Vignoles and John Macneill, and produced a remarkable report of over 700 pages (including a variety of appendices) with a design for a comprehensive system of railways for that country ${ }^{39}$.

\section{Railway system counterfactuals and effects of industrial policy}

Biddle's criticism, which in principle applies to all counterfactuals, seems to go too far. Casson's study is very valuable in showing in a precise quantitative form how much inefficiency had accumulated in the British railway system. It would be even more valuable if we had similar counterfactuals for other systems from that era, to see what effect various types of planning had. The railway system of India, for example, is a natural object of study. So is the Irish system, where we can compare the system recommended by the Commission of late 1830s to what was actually built, and to what would have been optimal for 1914 .

Perhaps the most interesting comparison would be with the Belgian system, which, properly speaking, was the the world's "first railway system," in that it was the first to be planned as a whole. Soon after gaining their independence from the Netherlands, the Belgians designed and built "a radical, top-down, territory-covering instrument" [8]. By the early 1840s Belgium had a unified system of 345 miles, built and operated by the government. That was far short of the extent of British or American railways, but relative to either territory or population, it had the highest density in the world. A project similar to Casson's, evaluating the efficiency of the system that developed in Belgium in the rest of the 19th century (through both government and private construction) would be very enlightening.

Many other European systems would also be valuable objects of study, since they invariably involved central government planning. Even more interesting would be studies of the American railroad network. In common with the British one, it grew up in a decentralized fashion. However, it was built based on very different principles, as was mentioned in Section 4. Costs were far lower than in Britain as a result of different design decisions, driven by a different environment, with higher costs of capital and higher growth rates. Counterfactuals could provide us with insights into whether the contrasting American and British approaches were optimal for their respective countries. They could also allow for an evaluation of whether the British railway building style was optimal for some of the other countries where it was adopted (such as Argentina, Australia, India). Would those countries have been better off following the American model and building something cheaply to a low standard first, and rebuilding later? This issue does not appear to have been considered in the literature.

\section{Conclusions}

Casson's thesis that a slight change in policy in 1845 would have produced a dramatically more efficient railway system for Britain by 1914 appears very improbable. The public and 
the policy makers of that time did not have the information that Casson, with the benefit of more than a century and a half of experience, could base his plans on. In particular, in those "early modern" times, prevailing notions of locality of traffic and of growth rates (for railways and for the economy as a whole) were incorrect. Given those incorrect notions, it is quite likely that a stronger role for government planners would have produced an even less efficient network.

On the other hand, most of the work that went into Casson's project has high value. Important insights into the potential of industrial policy, when faced with a revolutionary new technology, could be obtained if counterfactuals similar to Casson's were produced for other railway systems of that period.

\section{Acknowledgments}

Thanks are due to the anomymous referees for their comments and suggestions. The many individuals and institutions that assisted in the project on technology bubbles from which this paper is derived are listed at

〈http://www.dtc.umn.edu/ odlyzko/doc/mania-ack.html〉.

\section{Notes}

${ }^{1}$ Railway Times, 3 July 1847, pp. 871-875.

${ }^{2}$ Railway Times, 5 and 8 January 1839, includes Brunel's response.

${ }^{3}$ Parliamentary Papers, 1846 (687) XIV.5, Q1526.

${ }^{4}$ Speech of 11 May 1836, reprinted in [22].

${ }^{5}$ The Times, 17 September 1846, p. 5.

${ }^{6}$ The Times, 16 December 1844, p. 5.

${ }^{7}$ Parliamentary Papers 1852-53 (170) XXXVIII.5. This report contains both Laing's and Stephenson's testimony.

${ }^{8}$ Morning Chronicle, 9 Sept. 1853, p. 3.

${ }^{9}$ Minutes of Proceedings of the Institution of Civil Engineers, vol. 15, 1856, p. 139.

${ }^{10}$ Spencer's essay was reprinted in the 25 November and 2 December 1854 issues. The commentary, which was published anonymously, but which it seems safe to attribute to Poor, appeared in those two issues as well as the next two. Poor's commentary was in turn reprinted by Spencer in the book version of his essay [27], which had first appeared in Edinburgh Review in October 1854.

${ }^{11}$ Prospectus of the line, The Times, 12 August 1845, p. 10. John Dillon, James Morrison's partner in the Fore-street textile business, was the temporary Chairman of the Committee of Management at that stage. 
12 The Times, 5 May 1839, p. 3.

${ }^{13}$ Parliamentary Papers 1845 (118) XXXIX.411.

${ }^{14}$ Railway Times, 15 November 1845, pp. 2228-2229.

${ }^{15}$ The Times, 16 December 1844, p. 5.

${ }^{16}$ The Times, 15 November 1845, p. 4.

${ }^{17}$ The Times, 19 November 1845, p. 4.

${ }^{18}$ Herapath, 31 January 1846, pp. 154-155 and 14 February, pp. 217-218, for example.

${ }^{19}$ Railway Times, 4 December 1847, pp. 1484-90.

20 The Times, 3 July 1837, p. 6.

21 "Report on the Manchester and Leeds Railway Bill," Supplement to Votes, House of Commons, 5 May 1836.

${ }^{22}$ Morning Chronicle, 12 September 1846, p. 2.

${ }^{23}$ Economist, 8 November 1845, p. 1110.

${ }^{24}$ Herapath, 26 February 1848, p. 229.

${ }^{25}$ The Times, 22 September 1849, p. 4.

${ }^{26}$ Money Market Examiner, 29 September 1849, pp. 517-19.

${ }^{27}$ Minutes of Proceedings of the Institution of Civil Engineers, vol. 15, 1856, p. 127.

${ }^{28}$ Parliamentary Papers 1906 [Cd. 3106] CVI.601.

${ }^{29}$ Parliamentary Papers 1852-53 [1696] LV.1, p. ix. The authorization mileage is given there as 12,561, but that includes Ireland, so 1,061 was subtracted as an approximation.

${ }^{30}$ Parliamentary Papers 1847-48 (731) LXIII.275.

${ }^{31}$ Supplement and Appendix to Votes and Proceedings, House of Commons, 1844.

${ }^{32}$ Table in Railway Chronicle, 16 August 1845, p. 1015, and in Morning Post of that same day, p. 3.

${ }^{33}$ Parliamentary Papers 1852-53 (170) XXXVIII.5, Q990.

${ }^{34}$ Parliamentary Papers 1846 (687) XIV.5, Q1154.

${ }^{35}$ Parliamentary Papers 1844 (318) XI.17, p. xv.

${ }^{36}$ Various figures are available, even in official government sources, but they do not differ substantially. The numbers of railway acts are taken from Parliamentary Papers 1867 [3844] [3844-I] [3844-II] [3844-III] XXXVIII Pt.I.1, 127, XXXVIII Pt.II.1, 579, Appendix EK. The numbers of projects cited here refer just to those projects that survived the preliminary scrutiny on Standing Orders, and were assigned to the "committees on merits." For 1845, the figure is derived from Parliamentary Papers 1845 (620) XXXIX.7. For 1846, it is obtained from the 25 reports of that year's Select Committee on Railway Bills Classification, Parliamentary Papers 1846, vol. XIII. 
${ }^{37}$ Railway Record, 11 January 1845, pp. 37-38.

38 The Times, 16 Dec. 1844, p. 5.

${ }^{39}$ Parliamentary Papers 1837-38 [145] XXXV.449. 


\section{References}

1. W. Bagehot, Memoir of the Right Hon. James Wilson, H. Bale, 1861.

2. G. Biddle, letter to the editor on The World's First Railway System, J. Railway and Canal Historical Society, vol. 38, no. 209, Nov. 2010, p. 191.

3. Special Reports of Committees on Railway Bills Relating to the Adoption or Rejection of the Recommendations of the Board of Trade, Sess. 1845, James Bigg and Son, 1845.

4. G. Boyes, review of M. Casson, The World's First Railway System, J. Railway and Canal Historical Society, vol. 38, no. 208, July 2010, p. 131.

5. M. Casson, The World's First Railway System: Enterprise, Competition, and Regulation on the Railway Network in Victorian Britain, Oxford Univ. Press, 2009.

6. E. D. Chattaway, Railways: Their Capital and Dividends, ..., J. Weale, 1855.

7. C. Davies, review of Casson's The World's First Railway System, Economic Affairs, vol. 30, no. 3, 2010, pp. 99-101.

8. G. De Block, "Designing the nation: The Belgian railway project, 1830-1837," Technology and Culture, vol. 52, no. 4, Oct. 2011, pp. 703-732.

9. R. Gatty, Portrait of a Merchant Prince: James Morrison, 1789-1857, Pepper Arden, 1977.

10. T. Gourvish, review of Casson's The World's First Railway System, Economic History Review, vol. 63, no. 3, 2010, pp. 818-819.

11. W. A. Graham, "Adaptation of official returns of railway traffic to the general purposes of statistical inquiry," J. Statistical Society of London, vol. 8, no. 3, Sept. 1845, pp. 215236.

12. J. C. Jeaffreson, The Life of Robert Stephenson, F.R.S., .., with chapters by W. Pole, 2 vols., Longman, Green, Longman, Robert \& Green, 1864.

13. J. R. Kellet, Railways and Victorian Cities, Routledge \& Kegan Paul, 1979.

14. R. W. Kostal, Law and English Railway Capitalism, 1825-1875, Oxford Univ. Press, 1994.

15. D. Lardner, The Steam Engine Explained and Illustrated, 7th ed., Taylor and Walton, 1840.

16. D. Lardner, "Correspondence between Dr. Lardner and the Editor," American Repertory of Arts, Sciences, and Manufactures, vol. 4, no. 4, Nov. 1841, pp. 246-254.

17. D. Lardner, "Railways at home and abroad," Edinburgh Review, vol. 84, no. 170, Oct. 1846, pp. 479-531.

18. H. C. G. Matthew and B. Harrison, eds., Oxford Dictionary of National Biography, Oxford Univ. Press, 2004.

19. E. T. MacDermot, History of the Great Western Railway: Volume One 1833-1863, revised by C. R. Clinker, Ian Allen, 1964. (Original edition 1927.)

20. B. R. Mitchell, British Historical Statistics, Cambridge Univ. Press, 1988.

21. J. Morrison, Observations Illustrative of the Defects of the English System of Railway Legislation, ..., Longman, Brown, Green, and Longmans, 1846.

22. J. Morrison, The Influence of English Railway Legislation of Trade and Industry: With an Appendix of Tracts and Documents, Longman, Brown, Green, and Longmans, 1848.

23. A. M. Odlyzko, "Collective hallucinations and inefficient markets: The British Railway Mania of the 1840s," 2010 manuscript available at 〈http://ssrn.com/abstract=1537338 . 
24. A. M. Odlyzko, "The collapse of the Railway Mania, the development of capital markets, and the forgotten role of Robert Lucas Nash," Accounting History Review, vol. 21, no. 3, Nov. 2011, pp. 309-345. Extended preprint available at $\langle$ http://ssrn.com/abstract $=1625738\rangle$.

25. A. M. Odlyzko, "The forgotten discovery of gravity models and the inefficiency of early railway networks," OEconomia, vol. 5, no. 1, 2015, pp. 157192, available at $\langle$ http://oeconomia.revues.org/1684〉. Preprint available at $\langle$ http://ssrn.com/abstract $=2490241\rangle$.

26. B. Poole, "Economy of railways," paper and abstract of discussion, Minutes of Proceedings of the Institution of Civil Engineers, vol. 11, 1852, pp. 450-477.

27. H. Spencer, Railway Morals and Railway Policy, Longman, Brown, Green and Longmans, 1855.

28. C. Wrigley, review of Casson's The World's First Railway System, Business History Review, vol. 84, no. 3, 2010, pp. 607-608. 